\title{
Lårhalsbrudd - Norske data
}

\author{
Haakon E. Meyer \\ Statens helseundersøkelser, Postboks 8155 Dep, 0033 Oslo
}

\begin{abstract}
Antall lårhalsbrudd har økt kraftig de senere tiår, og vi regner nå med at omlag 8000 nordmenn årlig får et nytt lårhalsbrudd. Denne økningen kan delvis forklares ut fra at det er blitt flere eldre, men samtidig har insidensen av brudd i de forskjellige aldersklasser $ø$ kt. En analyse basert på Statistisk sentralbyrås fremskrivning av folkemengden tyder på at vi kan få en fordobling av antall lårhalsbrudd de neste 50 år dersom de alders- og kjønnsspesifikke ratene holder seg uforandret.

Insidensen av lårhalsbrudd varierer mye fra befolkning til befolkning. Skandinaviske kvinner og menn synes å være spesielt utsatt for å få lårhalsbrudd, og noen av de høyeste bruddratene som er rapportert internasjonalt kommer fra Oslo. Vi utførte en case-control studie blant ikke-institusjonaliserte eldre i Oslo for å kartlegge risikofaktorer for lårhalsbrudd i denne høy-insidens befolkningen (1). Alle pasienter som ble innlagt på Aker og Lovisenberg sykehus med lårhalsbrudd $\mathrm{i}$ ettårsperioden februar 1992 til februar 1993 ble registrert. I overkant av 5\% av samtlige kvinner 90 år og eldre bosatt $\mathrm{i}$ dekningsområdene til de to sykehusene fikk lårhalsbrudd i løpet av det året studien pågikk. Tilsvarende tall for aldersgruppen 80-84 år (kvinner) var ca. 2,5\%.

Til hver enkelt av lårhalsbruddpasientene som møtte inklusjonskriteriene til case-control studien (248 pasienter) ble det plukket en tilfeldig kontrollperson bosatt i dekningsområdene til de to sykehusene. Det ble foretatt matching for kjønn og alder
\end{abstract}

(innen 4 årsgrupper). Cases og kontroller ble intervjuet $i$ følge et 6 siders spørreskjema der det ble innhentet informasjon vedrørende kostvaner, fysisk aktivitet, høyde/vekt, tidligere sykdommer, medikamentbruk etc. I tillegg ble hudfoldtykkelsen målt (triceps) med en caliper og håndgrepsstyrken ble målt med et dynamometer. Den statistiske analysen ble foretatt ved hjelp av betinget logistisk regresjon.

Vi fant at magre personer (lav body mass index/ liten hudfoldtykkelse) hadde en betydelig forhøyet risiko for lårhalsbrudd, og hele $32 \%$ av de kvinnelige lårhalsbruddpasientene hadde en hudfoldtykkelse på $12 \mathrm{~mm}$ eller mindre, som er ett (av flere) kriterier for underernæring. Personer med selvoppgitt vekttap p.g.a. nedsatt appetitt hadde også økt risiko for brudd. Videre fant vi at de som oppga at de spiste færre enn 3 måltider per dag, de som spiste mindre enn 3 brødskiver per dag og de som ikke spiste middag daglig var mer utsatt for brudd. Imidlertid fant vi ikke noen sammenheng mellom kalsiuminntak og lårhalsbrudd $\mathrm{i}$ denne studien, mens den antydet en økt risiko for brudd hos de med lavt inntak av vitamin D. Vi fant videre at de som oppga at de var fysisk inaktive hadde forhøyet risiko for brudd, og tilsvarende var det en sammenheng mellom nedsatt muskelstyrke og brudd. Totalt sett var risikofaktormønsteret for lårhalsbrudd blant eldre i Oslo mye det samme som tidligere beskrevet $\mathrm{i}$ andre populasjoner. I tillegg fant vi en sammenheng mellom lavt fødeinntak og lårhalsbrudd, en sammenheng som tidligere har vært lite studert.

\section{REFERANSE}

1. Meyer HE, Henriksen C, Falch JA, Pedersen JI, Tverdal A. Risk factors for hip fracture in a high incidence area: A case-control study from Oslo, Norway. Osteoporosis Int 1995; 5: 239-246. 